\title{
Menumbuhkan Minat Budaya Literasi di Kalangan Kaum Milenial: Studi Kasus Pelajar MAN 1 Lamongan
}

\author{
Jihan Rafifah Mahdiyyah ${ }^{1}$, Moses Glorino Rumambo Pandin ${ }^{2}$ \\ ${ }^{1}$ Program Studi Bahasa dan Sastra Inggris, Fakultas Ilmu Budaya, Universitas Airlangga \\ ${ }^{2}$ Departemen Bahasa dan Sastra Inggris, Fakultas Ilmu Budaya, Universitas Airlangga
}

\begin{abstract}
Abstrak
Penelitian ini memiliki tujuan untuk menganalisa praktik Gerakan Literasi Sekolah guna mendorong budaya baca tulis di Man 1 Lamongan. Adapun teknik pengambilan data melalui observasi wawancara dan tinjauan pustaka berdasarkan riset penelitian terlebih dahulu. Hasil penelitian menunjukkan bahwa praktik Gerakan Literasi Sekolah di Man 1 Lamongan telah sesuai. Beberapa program yang ada untuk mendorong siswa siswi gemar membaca berupa Buku Jambu Sikat Petang dan Literasi Agama Membaca Al-Quran. Pelaksanaan program tersebut dilakukan pada pagi hari setiap sebelum memulai kegiatan belajar mengajar untuk mengontrol perkembangan siswa terhadap budaya literasi.
\end{abstract}

Keywords : Literasi, Desa, Budaya Baca

\section{Pendahuluan}

Pada era digital saat ini, masyarakat umum difasilitasi dengan kecanggihan teknologi yang lebih berkembang dan lebih cepat sehingga lapisan masyarakat mengalami kemrosotan sehubungan dengan persepsi dan sains karena kurangnya budaya literasi. Kemajuan teknologi yang berkembang dengan cepat memunculkan banyak fenomena baru di antara orang-orang di sekitar contoh yang awalnya dilakukan kegiatan nyata sekarang menggunakan kegiatan dunia maya. Literasi adalah kegiatan yang dilakukan untuk mengetahui dan memahami pengetahuan yang telah diperoleh baik di lingkungan umum dan di lingkungan pendidikannya. Dalam deklarasi prahara (2003) menjelaskan bahwasanya literasi merupakan cara seseorang berkomunikasi dengan masyarakat sekitarnya. Di era modern ini, literasi lebih dari sekadar membaca dan menulis, tetapi juga termasuk keterampilan dalam berpikir dengan menggunakan berbagai sumber pengetahuan, baik berupa audio, visual dan digital.

Pada saat ini budaya literasi masih belum menyebar menyeluruh ke semua lapisan masyarakat di Indonesia. Oleh sebab itu perilaku atau kebiasaan masyarakat harus ada perubahan yang mulanya tidak suka membaca menjadi gemar membaca. Sebagai hasil dari pengembangan teknologi informasi yang cepat ini, orang memulai menggunakan berbagai jenis fasilitas teknologi seperti penggunaan gadget atau fasilitas teknologi canggih lainnya yang kadangkadang digunakan tanpa bijaksana. Lapisan masyarakat terjun di dunia permainan dan media sosial lainnya yang kadang-kadang juga menggunakan banyak sisi negatif daripada sisi positif. Eric Schmidt (Fatmawati, N.I. (2019), insiyur dari Google, memperkirakan pada tahun 2020 kedepan seluruh manusia di dunia akan didominasi pada kegiatan tatap muka terbatas (daring). 
Faktanya. Hal tersebut telah terjadi sekarang. Kecanggihan teknologi telah menyebar tidak melihat usia orang dewasa dan anak-anak semua telah menggunakan berbagai jenis fasilitas digital dalam berbagai bentuk. Khususnya dalam penggunaan fasilitas digital jika di rumah itu tidak jarang mereka cenderung lebih sibuk dengan perangkat digital mereka daripada berinteraksi di antara sesama anggota dalam keluarga untuk menciptakan harmoni hal ini juga terjadi ketika dalam hal kumpul-kumpul sesama teman. Teknologi informasi yang cepat kekuatan utamanya adalah pengetahuan atau informasi yang menjadi upaya untuk menjangkau berbagai pihak dalam menyampaikan informasi yang termasuk dalam dunia pendidikan dan proses perkembangan pembelajaran. Sekarang ini dimasa pandemi pembelajaran juga banyak menggunakan kemajuan digital untuk metode pembelajaran daring.

Literasi pada saat ini belum tertanam kuat dan menjadi kebiasaan di negara kita, orang-orang cenderung memilih untuk menonton atau mendengar dibandingkan dengan membaca atau menulis. Menurut Hasanah dan Deiniatur berpendapat literasi itu tidak hanya basic skill untuk membaca, menghitung, dan menulis. Literasi dalam arti modern adalah termasuk keterampilan bahasa, penghitungan, menafsirkan gambar, komputer dan upaya-upaya untuk mendapatkan wawasan. Pada era digital saat ini semua bisa diakses melalui internet. Pada zaman saat ini d iera digital yang semakin maju jarang ditemui kaum milenial yang gemar membaca atau menjadikan membaca sebagai hobi. Mereka cenderung suka bermain smartphone baik digunakan untuk bersosial media maupun untuk main game setiap harinya. Kaum milenial ini masih kurang dalam pemahaman akan pentingnya membaca daripada bermain smartphone seharian tanpa adanya manfaat kepada dirinya sendiri sama sekali. Pada kenyataannya generasi milenial ini banyak sekali yang malas membaca dengan seiring perkembangan zaman yang semakin maju.

Teknologi informasi yang berkembang pesat membuat semua orang lebih mudah mengakses berbagai informasi yang mereka inginkan. Dengan perkembangan ini harusnya seimbang dengan menjadikannya sebagai sarana membaca. Karena pada era saat ini sudah banyak e-book yang seharusnya dimanfaatkan masyarakat terutama kaum milenial untuk menumbuhkan budaya literasi di Indonesia. Tetapi kembali lagi dengan masalah yang ada pada masyarakat, terutama generasi milenial yang kurang tertarik pada budaya membaca. Membaca adalah upaya untuk meningkatkan kesejahteraan dan merupakan kebutuhan dasar yang harus dilakukan oleh seseorang untuk mengubah dirinya dengan lebih baik. Membaca juga merupakan sarana untuk mendapatkan pengetahuan tentang informasi dan wawasan dari apa yang dia baca. Karena alasan ini, diharapkan bahwa generasi milenial sadar terhadap kepentingan membaca di mana bacaan sangat penting dan menambah wawasan kita menjadi lebih luas. Crow dan crow mengatakan bahwa ada lima indikator yang dapat mempengaruhi minat baca yaitu: motivasi, waktu, emosi, usaha guna membaca, beserta pemusatan perhatian.

Tingkat literasi di negara Indonesia di antara masyarakat umum berada di level terendah. Minat membaca orang Indonesia diklasifikasikan sebagai sangat mengkhawatirkan dengan persentase $0,001 \%$. Ini berarti bahwa seribu orang Indonesia hanya terdapat satu orang yang rajin membaca. UNESCO mengatakan bahwasanya negara Indonesia merupakan negara peringkat kedua dari bawah dalam hal literasi. Berdasarkan penelitian yang dilakukan oleh United Nations 
Development Programme (UNDP) Level Pendidikan Indonesia rendah dengan persentase 14,6\%. Ini cukup jauh dari negara lain. Hasil tersebut menunjukkan bahwa kemampuan literasi pelajar yang berada di Indonesia umumnya relatif rendah, terutama dalam hal literasi Bahasa.

Terdapat berbagai hal yang dapat menyebabkan minat baca masyarakat Indonesia masih tergolong rendah. Yang pertama, kurangnya penanaman gemar membaca yang dilakukan sejak usia dini. Yang kedua, kurangnya fasilitas dan sedikitnya kualitas sarana prasarana bidang pendidikan. Yang ketiga, kurangnya pasokan produksi buku atau berkurangnya penerbit buku sehingga minim bahan buku bacaan. Yang keempat, kurangnya sosialisasi mengenai pentingnya kebiasaan literasi bagi masyarakat.

\section{Metode}

Penelitian ini merupakan peneliyian kualitatif untuk menggambarkan masalah dan fokus penelitian. Menurut Lexy J. Moeolong (2007:11), metode kualitatif merupakan langkah-langkah penelitian sosial guna mendapatkan data deskriptif dalam bentuk kata dan gambar. Pendekatan kualitatif ialah pencarian yang menunjukkan prosedur penilaian dimana menghasilkan data deskriptif dalam bentuk kata-kata tertulis oleh orang dan perilaku yang diamati. Dalam hal ini, para peneliti menjelaskan data yang diperoleh oleh peneliti berupa wawancara atau observasi, dan dokumentasi, sehingga mereka memperoleh jawaban atas masalah secara terperinci dan eksplisit.

Berdasarkan fokus masalah, peneliti menggunakan metode penelitian kualitatif deskriptif. Penelitian kualitatif deskriptif merupakan metode penelitian yang bertujuan untuk menggambarkan fenomena yang terjadi dengan menggambarkan suatu kondisi sesuai apa adanya. Jenis penelitian ini merupakan jenis penelitian studi kasus. Subjek yang diambil dalam penelitian adalah memilih remaja milenial MAN 1 lamongan karena subjek tersebut tumbuh di zaman majunya teknologi. Penelitian ini mengambil lokasi penelitian melalui platform online. Hal tersebut berkaitan dengan kondisi yang belum memungkinkan melakukan penelitian secara langsung. Adapun teknik pengumpulan data yang digunakan sebagai berikut:

Wawancara merupakan teknik pengumpulan data dalam sebuah penelitian melalui pengadaan dialog dengan narasumber. Sementara itu, dalam buku Burhan Bingim dijelaskan bahwasanya wawancara dilakukan dengan cara mengumpulkan data dan informasi melalui bertemu secara tatap muka secara langsung dengan informan, dengan maksud untuk mendapatkan gambaran lengkap dari topik yang dipelajari. Namun, dalam penelitian ini peneliti menggunakan tatap muka secara terbatas karena adanya pandemi dan teknik wawancara yang tidak terstruktur. Menurut Mulyana, awancara tidak terstruktur merupakan wawancara yang fleksibel, maknanya kemauan pertanyaan dan kata-kata dalam setiap pertanyaan dapat diubah oleh peneliti dalam wawancara, disesuaikan dengan kebutuhan dan kondisi selama wawancara, termasuk tingkat sosial budaya, agama, kesukuan, gender, usia, tingkat pendidikan. Karakteristik, dan profesi.

\section{Hasil Temuan Data}


Berdasarkan hasil observasi wawancara dan tinjauan pustaka, literasi di Man 1 Lamongan telah menunjukkan kegiatan literasi yang sesuai dengan koridor Gerakan Literasi Sekolah. Hal ini dapat ditinjau tahap-tahap pelaksanaan dalam melaksanakan Gerakan literasi. Program tersebut juga telah memenuhi standar prinsip-prinsip literasi sekolah. Dilihat dari kegiatan literasi yang berjalan sesuai dengan perkembangan berupa strategi pembiasaan diri beserta pembelajaran yang sesuai. Di Man 1 Lamongan menunjukkan pembiasaan dilakukan dengan meminta siswa siswi membaca setiap hari baik buku literature maupun Al-Quran. Kedua, program literasi tersebut berjalan secara seimbang. Seluruh kalangan pelajar berpartisipasi. Selanjutnya terintegrasi sistem kurikulum. Artinya, program literasi tanggung jawab semua guru dan wali kelas dengan pengawasan misalnya saat membaca Al-Quran dan unjuk bukti tanda tangan orang tua dalam buku Jambu Sikat Petang. Kemudian, program literasi dapat dilihat dari hasil karya dan prestasi siswa. Kelima, mengembangkan budaya lisan yang merupakan inisiatif siswa untuk membentuk small group, dan juga partisipasi siswa pada lomba literasi yang diselenggarakan sekolah. Yang terakhir, pengembangan kesadaran untuk mempertahankan budaya literasi,

\section{Pembahasan}

\section{Literasi Di Era Digital}

Pada era digital yang semakin maju dan berkembang di dunia, saat ini menjadi tantangan dalam hal menumbuhkan budaya literasi di kaum milenial. Kaum milenial sekarang banyak yang lebih memilih bermain smartphone daripada harus membaca buku yang seolah membosankan bagi mereka di era digital saat ini. Hampir setiap kaum milenial sekarang menghabiskan waktunya tak lepas dari genggaman smatrphone pribadinya setiap hari. Di era yang semakin maju, semakin memudahkan setiap orang untuk mengakses informasi hanya melalui genggaman smartphone. Hal ini membuat banyak pelajar ketika ada soal tugas dari guru hanya bergantung pada jawaban google yang bisa diakses secara cepat dan instan yang menjadikan mereka tambah malas untuk membaca. Fenomena inilah yang banyak terjadi di Indonesia saat ini terhadap kaum milenial.

Pada dasarnya kemajuan digital saat ini, tentu mempunyai dampak positif dan negatifnya. Pemanfaatan kemajuan digital harus dimanfaatkan secara positif. Banyak sekarang kaum milenial yang malah dengan adanya kemajuan digital saat ini malah menjadi dampak negatif baginya. Seperti menghabiskan waktu seharianya hanya untuk bermain game dan bersosial media melalui smartphone hingga lupa waktu dan tidak ada manfaatnya positif bagi dirinya sendiri. Saat ini Literasi sangat penting ditumbukan kepada masyarakat terutama kaum milenial. Literasi yang baik dapat menangkal adanya berita hoax yang sekarang gampang tersebar di era digital yang semakin maju. Minimnya literasi membuat seseorang mudah termakan oleh berita hoax yang banyak saat ini. Kemajuan teknologi saat ini tentunya harus diimbangi dengan sumber daya manusia yangbermutu, cerdas memanfaatkan kemajuan contohnya seperti saat ini sudah banyak e-book yang bisa untuk menambah wawasan dan pengetahuan hanya melalui smartphone pribadi. Kemajuan di era digital saat ini bisa berdampak positif dan negatif tergantung pemanfaatan pribadi masing-masing. 


\section{Menumbuhkan literasi kaum milenial di era digital}

Tingkat literasi di negara Indonesia di antara masyarakat umum berada pada level terendah. Minat membaca orang Indonesia diklasifikasikan sebagai sangat mengkhawatirkan dengan persentase $0,001 \%$. Ini berarti bahwa seribu orang Indonesia hanya terdapat satu orang yang membaca dengan rajin. UNESCO mengatakan bahwa negara Indonesia diklasifikasikan kedua dari bawah dalam hal literasi. Dilihat oleh data penelitian yang dilakukan oleh UNDP dari rendahnya tingkat pendidikan Indonesia dengan persentase 14,6\%. Ini cukup jauh dari negara lain. Data diatas merupakan bentuk contoh bahwa budaya literasi belum tertanam kuat di negara kita Indonesia. Dalam menyikapi hal ini harusnya ada perubahan dari masyarakat yang tidak gemar membaca menjadi gemar membaca dan menjadikannya layaknya sebuah kebutuhan pokok setiap harinya.

Kaum milenial yang sekarang sebagaian masih menjadi pelajar maupun mahasiswa bisa menjadi penggerak dalam menumbuhkan minat budaya literasi disekitar masyarakat. Karena kaum milenial dianggap mempunyai gagasan yang brilian yang bisa menumbuhkan minat baca dimasyarakat dengan progam-progam menarik. Tetapi kenyataan juga masih banyak kaum milenial yang cenderung tidak gemar membaca dan lebih senang bermain game atau bersosial media di zaman serba digital saat ini. Dalam hal ini kesadaran akan pentingnya literasi untuk diri sendiri seharusnya mulai disadari. Pemahaman tentang pentingnya literasi dimasyarakat umum khususnya kaum milenial masih belum banyak yang mengetahui akan hal itu. Literasi penting bagi kehidupan setiap hari, terutama kaum milenial yang seharusnya setiap hari selalu menambah informasi dan wawasannya dengan gemar membaca.Kaum milenial saat ini masih banyak yang sering termakan oleh berita hoax disosial media maupun internet. Menumbuhkan budaya literasi dikaum milenial adalah satu mencegah termakannya hoax yang sekarang banyak ditemui disosial media atau internet di Indonesia.

Pada era digital saat ini kaum milenial bisa memanfaatkan perkembangan yang semakin maju untuk menguatkan literasi diri sendirinya. Kemajuan era digital tidak semuanya berdampak negatif, namun terdapat sisi positifnya yang dapat dimanfaatkan. Pemanfaatan untuk menambah minat baca dimasyarakat umum terlebih di kaum milenial saat ini. Saat ini buku sudah dapat diakses melalui smartphone dimana kecanggihan ini memudahkan seseorang yang malas ketika membuka buku tetapi sekarang sudah tersedia buku yang bisa diakses kapanpun melaui smartphoneE-book bisa menjadi terobosan di era digital saat ini untuk menumbuhkan minat baca kaum milenial. Karena mereka setiap harinya hampir menghabiskan waktunya dengan memegang smartphone. Hal ini mengurangi dampak negatif dari kemajuan digital saat ini. Namun perlu disadari literasi yang baik merupakan ada kesadaran pada dirinya untuk merubah kebiasaanya. Menumbuhkan budaya literasi dapat dimulai dari diri sendiri dan yang paling kecil keluarga.

\section{Praktik Literasi di MAN 1 Lamongan}


Madrasah Aliyah Negeri 1 Lamongan telah menerapkan program literasi dimulai sejak siswa siswi berada di bangku kelas X. Berkenaan dengan itu Aisyah Nur Mahmudah selaku siswa kelas XI MIPA 1 mengatakan bahwasanya bentuk literasi pada awalnya sudah diajarkan lewat beberapa mata pelajaran diharuskan meminjam melalui perpustakan yang dimaksudkan untuk menambah dan menunjang buku pelajaran siswa. Program ini telah berlangsung selama berkelanjutan dimana dapat mendorong siswa untuk semakin memiliki minat membaca buku. Program ini juga dapat mendorong mereka guna membentuk small group dengan saling berdiskusi satu sama lain sehingga budaya ini dapat menular dari satu siswa ke sesama grup mereka.

Program literasi juga dikembangkan dari hasil karya siswa yang diterbitkan ke dalam majalah tahunan oleh tim jurnalistik Man 1 Lamongan yang biasanya diterbitkan di masa kenaikan kelas. Margareza Dwi Wahyuni menuturkan bahwa:

"Tim Jurnalistik MAN 1 Lamongan sangat mendukung para siswa siwi untuk memiliki sifat gemar membaca dan menulis, biasanya di akhir periode atau kenaikan kelas mereka masuk ke kelas-kelas untuk memberikan peluang bagi siswa siswi menerbitkan karyanya di majalah yang terbit di akhir tahun pembelajaran”.(3/1/2022)

Untuk lebih menunjang praktik budaya literasi ini, Man 1 Lamongan mengadakan beberapa kegiatan pendukung berupa lomba pojok baca, puisi, dan menulis cerpen. Melalui kegiatan tersebut, diharapkan siswa menjadi lebih bersemangat dalam menulis dan membaca.

Untuk masalah ketersediaan buku literatur, dilansir dari jatim.kemenag.go.id, Pimpinan Perpustakan Siti Muzayati Rohmah menuturkan sudah tidak masalah. Karena, menurut beliau, pihaknya telah memperluas jaringan dan koneksi. Perpustakan MAN 1 Lamongan telah menjalin kerja sama dengan perpustakaan Universitas Airlangga Surabaya.

"Dengan Perpustakaan Universitas Airlangga, kita buat perjanjian dengan mereka untuk membina kita bagaimana cara mengolah dan mengembangkan perpustakaan," tutur dia (jatim.kemenag.go.id)

Selanjutnya praktik literasi juga didorong di kalangan madrasah dengan menulis buku laporan. Aisyah Nur Mahmudah, siswa MAN 1 Lamongan menjelaskan:

"Di Man 1 Lamongan ada sebuah program yang mendorong menumbuhkan budaya literasi di kalangan madrasah. Kita menyebutnya, Buku Jambu Batu Sikat Petang (Pinjam Buku Baca Tulis Prestasi Meningkat Petik Bintang). Kita sedari awal masuk kelas X sudah diberikan buku tersebut. Tiap hari disuruh mengisi. Tablenya ada 4: nomor, judul buku, penulis, dan berapa banyak halaman yang kita baca, serta isi rangkuman dari yang kita baca. "(3/1/2022) 
Man 1 Lamongan membentuk program buku Jambu Sikat Petang bertujuan memberikan wawasan bagi pelajar mengenai membaca dan menulis. Harapannya mereka setiap hari dengan mendapatkan wawasan tersebut, membaca menjadi habit bagi mereka untuk dilakukan setiap hari. Menurut keterangan dari Margareza Dwi Wahyuni selaku siswa Man 1 Lamongan bahwa dalam pelaksanaanya memang diwajibkan setiap hari untuk membaca. Kemudian, diminta untuk melaporkan apa yang dibaca melalui buku Jambu Sikat Petang. Buku tersebut diisi oleh siswa. Setiap satu bulan sekali, buku tersebut di kumpulkan ke guru mata pelajaran Bahasa Indonesia dengan terdapat tanda tangan orang tua. Wali kelas bertugas dalam memaparkan dan mengingatkan kapan buku tersebut akan dikumpulkan. Bukan hanya sebagai model yang bertujuan untuk menambah wawasan siswa tentang pentingnya kemampuan baca dan tulis, program literasi ini juga sebagai motivasi bagi para siswa terhadap pembuatan karya mandiri. Apabila siswa gemar membaca, mereka juga kerap menuangkan hasil pemikirannya ke dalam bentuk review buku, membuat dan menulis puisi, membuat cerpen, majalah dinding kemudian dikirim ke surat kabar atau majalah. Hal tersebut diungkapkan oleh Margareza selaku siswa kelas Bahasa:

"Kalau di kelas Bahasa, praktik literasi juga didukung oleh guru. Di jurusan ini, memang kami dituntut untuk gemar membaca dan menulis. Biasanya kami selepas menuntaskan satu novel, kami menuliskan rangkuman atau resensi dari novel tersebut. Hampir tiap bulan terdapat satu kerya resensi. Selain itu, kami juga diberi tugas untuk menulis puisi kemudian mengirimkannya ke beberapa penerbit seperti Radar Jatim, Jawa Pos, dll.” (3/1/2022)

Dalam buku Jambu Sikat Petang, selain digunakan untuk mengontrol aktivitas membaca siswa. Man 1 Lamongan juga menggunakan media ini guna ranah memberikan nilai tambahan pada mata pelajaran Bahasa Indonesia. Apabila dalam satu bulan siswa membaca penuh, akan diberi nilai A. Apabila siswa membaca 15 hari lebih, siswa mendapatkan nilai B. Namun, apabila siswa tidak membaca sama sekali, konsekuensinya tetap mengisi buku tersebut. Buku Jambu Sikat Petang ini menurut informasi dari salah satu Alumni, Bagus Dwi Ramadhan, menjadi syarat untuk pengambilan ijazah kelulusan. Selama 3 tahun, terdapat catatan yang sudah mengumpulkan dan yang belum mengumpulkan. Untuk bisa mengambil ijazah, buku Jambu harus berjumlah 3: Kelas X, Kelas XI, dan Kelas XI.

Pada praktiknya, literasi di Man 1 Lamongan bukan hanya membaca buku seperti buku pembelajaran, komik, novel, dan lain-lain. Akan tetapi, juga terdapat literasi membaca AlQur'an. bentuk literasi membaca Al-Quran ini juga selaras dengan visi Man 1 Lamongan yaitu Terwujudnya Madrasah Digital yang Unggul. Pada dasarnya tahapan implementasi yang dilaksanakan melalui pembiasaan. Sebelum pembelajaran dimulai, para siswa siwi melaksanakan kegiatan tersebut dimana berlangsung selama 15 menit pada hari Senin-Sabtu dengan bimbingan dan pengawasan guru yang mengajar pada jam pertama pembelajaran. Hal ini ni dilakukan agar 
siswa mempunyai niat dan kemauan membaca tanpa adanya paksaan atau karena diminta oleh guru. Pengembangan praktik literasi di sekolah dalam bentuk literasi membaca Al-Quran menjadi penting karena berkaitan dengan penguatan pemahaman keagamaan siswa melalui melantunkan ayat-ayat Al-Quran kemudian dengan itu mereka dapat menerjemahkan artinya kemudian mendalami asbabun nuzul dan makna dari ayat yang dilantunkan. Dengan begitu siswa siswi dapat mempelajari agama lebih intens dan berfrekuensi. Praktik iterasi agama juga secara tidak langsung telah membantu memaksimalkan pelajaran agama di sekolah karena mata pelajaran agama di sekolah seringkali dikaitkan dengan problem jam pelajaran yang membosankan.

Pada dasarnya, kegiatan literasi berupa membaca Al-Quran yang diterapkan oleh Man 1 Lamongan ini juga menjadi perbedaan Man 1 Lamongan dengan sekolah lainnya. Terlebih lagi Man 1 Lamongan yang merupakan sekolah agama. Negara Indonesia bukanlah negara sekular. Oleh karena itu, dalam pelaksanaan sitem pendidikan, pendidikan agama juga terintegrasi dalam pendidikan nasional dimana mempunyai dasar hukum yang kuat. Hal tersebut bertujuan untuk meningkatkan kesadaran hidup warga Indonesia akan pentingnya agama.

\section{Kesimpulan}

Berdasarkan penjelasan di atas, dapat disimpulkan bahwasannya Man 1 Lamongan dalam mebudaya literasi di kalangan pelajar menggunakan beberapa program, yakni buku Jambu Sikat Petang, Membaca Al-Quran, dan Lomba Pojok Baca. Kegiatan tersebut diantaranya:

a. Program lomba pojok merupakan revitalisasi perpustakaan berupa dalam pengadaan atau penambahan buku, penataan tempat/ruang, pelibatan publik, dan penghargaan yang diberikan kepada kelas yang kreative dalam menunjang tempat literasi.

b. Pada program membaca Al-Quran yang dilakukani setiap pagi hari sebelum pembelajaran, mendidik siswa dalam memahami tentang pentingnya membaca dan membiasakan membaca Al-Quran per hari satu maqra'.

c. Program buku Jambu Sikat Petang dilakukan oleh siswa pertama dengan membaca kemudian menuliskannya dalam buku setiap harinya kemudian mengumpulkan buku tersebut untuk di tanda tangani oleh guru kemudian dilaporkan ke wali didik siswa. Kegiatan ini di tanda tangani olehguru setiap bulan bersamaan dengan kegiatan tulis resensi buku. Adapun tujuan dari kegiatan ini, dapat memberikan motivasi bagi para siswa dalam kegiatan literasi di sekolah dengan menumbuhkan minat membaca.

\section{REFERENSI}

1. Abrian, B. Y. (2017). Kompetensi Literasi Informasi di Kalangan Mahasiswa Strata Satu Universitas Airlangga (Doctoral dissertation, Universitas Airlangga).

2. Arikunto, Suharsimi. Prosedur Penelitian Suatu Pendekatan Praktik. Jakarta: Rineka Cipta, 2016. 
3. Baiq Arnika Saadati \& Muhamad Sadli "Analisis Pengembangan Budaya Literasi Dalam Meningkatkan Minat Membaca Siswa Di Sekolah Dasar”, (Terampil : Jurnal pendidikan dan pembelajaran Dasar).

4. Hasanah, U., \& Deiniatur, M. (2019). Membangun Budaya Membaca Pada Anak Usia Dini Di Era Digital. At-Tajdid: Jurnal Pendidikan dan Pemikiran Islam, 3(01), 10-24.

5. Imanda Fikri Aulinda "Menanamkan Budaya Literasi Pada Anak Usia Dini Di Era Digital", (Semarang : Universitas PGRI Semarang), Jurnal Pemikiran dan Pendidikan Anak Usia Dini, Vol.6 No.2., 2020.

6. Fatmawati, N. I. (2019). Literasi Digital, Mendidik Anak Di Era Digital Bagi Orang Tua Milenial. Madani Jurnal Politik Dan Sosial Kemasyarakatan, 11(2), 119-138.

7. Kharizmi, Muhammad. "Kesulitan Siswa Sekolah Dasar Dalam Meningkatkan Kemampuan Literasi.” Jurnal Pendidikan Almuslim 7, no. 2 (2019).

8. Mulyana, Dedy. Metodologi Penelitian Kualitatif, Paradigma Baru Ilmu Komunikasi Dan Ilmu Sosial Lainnya. Bandung: PT. Remaja Rosdakarya, 2008.

9. Muttaqin, M. Z. (2016). Kemampuan literasi media (media literacy) di kalangan remaja rural di Kabupaten Lamongan (Doctoral dissertation, Universitas Airlangga).

10. Mursyid, Moh. Membumikan Gerakan Literasi Di Sekolah. Yogyakarta: lembaga Ladang Kata, 2016.

11. Sukmadinata, Nana Syaodih. Metode Penelitian Pendidikan. Bandung: Rosda Karya, 2013

12. Lexy J. Moleong, Metodologi Penelitian Kualitatif, (Bandung: PT Remaja Rosdakarya, 2007), hal.11

13. Tugas Utami Handayani "Penguatan Budaya Literasi Sebagai Upaya Pembentukan Karakter", (Sukoharjo : Guru SMP 2 Sukoharjo), Jurnal Literasi, Vol.4 No.1., April 2020.

14. Utama, A. S. T. (2018). KEMAMPUAN LITERASI INFORMASI SISWA SMPNEGERI 1 SURABAYA (Doctoral dissertation, Universitas Airlangga).

15. Yuwinanto, H. P. (2013). PENGEMBANGAN LITERASI DAN PERILAKU GEMAR MEMBACA REMAJA.

16. Zeni, N. (2019). Tingkat Literasi Media Sosial Mahasiswa Ilmu Informasi Dan Perpustakaan Universitas Airlangga Surabaya Pada Grup Facebook "Iip Fisip Unair" (Doctoral dissertation, UNIVERSITAS AIRLANGGA).

Wawancara :

1. Wahyuni, M. D. Wawancara oleh Jihan Rafifah Mahdiyyah. Praktik Literasi di Man 1 Lamongan. 2022

2. Mahmudah, A. N. Wawancara oleh Jihan Rafifah Mahdiyyah. 2021. Pemahaman Literasi di Man 1 Lamongan. 2022 